\title{
Toxicity of reduced nitrogen in eelgrass (Zostera marina) is highly dependent on shoot density and $\mathrm{pH}$
}

\author{
T. van der Heide $\cdot$ A. J. P. Smolders $\cdot$ B. G. A. Rijkens $\cdot$ \\ E. H. van Nes • M. M. van Katwijk • J. G. M. Roelofs
}

Received: 1 January 2008 / Accepted: 8 September 2008 / Published online: 24 September 2008

(C) The Author(s) 2008. This article is published with open access at Springerlink.com

\begin{abstract}
In sheltered, eutrophicated estuaries, reduced nitrogen $\left(\mathrm{NH}_{x}\right)$, and $\mathrm{pH}$ levels in the water layer can be greatly enhanced. In laboratory experiments, we studied the interactive effects of $\mathrm{NH}_{x}, \mathrm{pH}$, and shoot density on the physiology and survival of eelgrass (Zostera marina). We tested long-term tolerance to $\mathrm{NH}_{x}$ at $\mathrm{pH} 8$ in a 5-week experiment. Short-term tolerance was tested for two shoot densities at both $\mathrm{pH} 8$ and 9 in a 5-day experiment. At $\mathrm{pH} 8$, eelgrass accumulated nitrogen as free amino acids when exposed to high loads of $\mathrm{NH}_{x}$, but showed no signs of necrosis. Low shoot density treatments became necrotic within days when exposed to $\mathrm{NH}_{x}$ at $\mathrm{pH}$ 9. Increased $\mathrm{NH}_{3}$ intrusion and carbon limitation seemed to be the cause of this, as intracellular $\mathrm{NH}_{x}$ could no longer be assimilated.
\end{abstract}

Communicated by Martin Attrill.

Electronic supplementary material The online version of this article (doi:10.1007/s00442-008-1155-2) contains supplementary material, which is available to authorized users.

T. van der Heide $(\bowtie) \cdot$ M. M. van Katwijk Department of Environmental Science, Institute for Wetland and Water Research, Radboud University Nijmegen, Faculty of Science, P.O. Box 9010, 6500 GL Nijmegen, The Netherlands

e-mail: t.vanderheide@science.ru.nl

T. van der Heide · A. J. P. Smolders · B. G. A. Rijkens •

J. G. M. Roelofs

Department of Environmental Biology,

Institute for Water and Wetland Research,

Radboud University Nijmegen, Faculty of Science,

P.O. Box 9010, 6500 GL Nijmegen, The Netherlands

E. H. van Nes

Aquatic Ecology and Water Quality Management Group, Department of Environmental Sciences, Wageningen University, P.O. Box 8080, 6700 DD Wageningen, The Netherlands
Remarkably, experiments with high shoot densities at $\mathrm{pH} 9$ showed hardly any necrosis, as the plants seemed to be able to alleviate the toxic effects of high $\mathrm{NH}_{x}$ loads through joint $\mathrm{NH}_{x}$ uptake. Our results suggest that $\mathrm{NH}_{x}$ toxicity can be important in worldwide observed seagrass mass mortalities. We argue that the mitigating effect of high seagrass biomass on $\mathrm{NH}_{x}$ toxicity is a positive feedback mechanism, potentially leading to alternative stable states in field conditions.

Keywords Alternative stable states $\cdot$ Ammonia . Ammonium toxicity $\cdot$ Density dependence $\cdot$ Necrosis . Positive feedback

\section{Introduction}

Seagrass meadows in tropical to temperate coastal areas are among the most productive ecosystems on earth, and harbor high biodiversity. They provide forage and refuge for a vast number marine animal species (Duarte 2002; Orth et al. 2006). At present, these ecosystems are increasingly being lost worldwide, often characterized by mass mortality of seagrasses (Jackson et al. 2001). Multiple stressors have been identified as causes for the decline (e.g., Duarte 2002; Orth et al. 2006). Seagrass losses have been ascribed to climate change (e.g., temperature and sea level rise), sedimentation, disease, turbidity, and toxicity events (e.g., Duarte 2002; Orth et al. 2006). In temperate estuaries, (anthropogenic) eutrophication is one of the most important processes fuelling turbidity and toxicity events (e.g., Goodman et al. 1995; Azzoni et al. 2001; Nielsen et al. 2002b; Kemp et al. 2005; Perez et al. 2007). Seagrass mass mortality in these areas has been linked with high concentrations of sulfide in the sediment pore water near the end of 
the growing season often in combination with high turbidity levels in the water layer (e.g., Carlson et al. 1994; Goodman et al. 1995; Azzoni et al. 2001; Pedersen et al. 2004). However, elevated levels of inorganic nitrogen in the water layer may also be important. These compounds have been shown to cause severe toxicity in seagrasses and may therefore help explain these dramatic events (Burkholder et al. 1992; van Katwijk et al. 1997; Bird et al. 1998; Brun et al. 2002).

In this perspective, toxicity caused by reduced nitrogen compounds $\left(\mathrm{NH}_{x}\right)$ is particularly interesting, as it is a common phenomenon described for a vast number of aquatic and terrestrial plant species (Britto and Kronzucker 2002). In seagrasses, ammonium $\left(\mathrm{NH}_{4}^{+}\right)$is taken up directly by both leaves and roots (Iizumi and Hattori 1982; Thursby and Harlin 1982; Rubio et al. 2007). Even though $\mathrm{NH}_{4}{ }^{+}$is preferred over nitrate $\left(\mathrm{NO}_{3}{ }^{-}\right)$as a nutrient source (Touchette and Burkholder 2000), it has been found to cause severe toxicity within weeks when concentrations become too high (van Katwijk et al. 1997; Bird et al. 1998; Brun et al. 2002). In seagrass beds growing in sheltered eutrophicated estuaries, $\mathrm{NH}_{x}$ concentrations may be greatly enhanced $\left(>200 \mu \mathrm{mol}^{-1}\right.$ ) by degradation processes inside competing macroalgal mats (Hauxwell et al. 2001), discharges of waste and river water (Brun et al. 2002), or due to natural die-off of phytoplankton, macroalgae, or seagrass itself near the end of the growing season (Landers 1982; Farnsworth-Lee and Baker 2000). Additionally, the pH in some of these stagnant lagoons may rise up to 9 or even 10 during daytime due to photosynthesis by the same species (Choo et al. 2002; Feike et al. 2007; our unpublished data). This in turn increases concentrations of highly toxic gaseous ammonia $\left(\mathrm{NH}_{3}\right)$, which is converted from ammonium as the $\mathrm{pH}$ level rises (e.g., Farnsworth-Lee and Baker 2000; Körner et al. 2001, 2003; Nimptsch and Pflugmacher 2007).

As $\mathrm{NH}_{x}$ is both a valuable nutrient source and a toxic substance for eelgrass, we hypothesize that its toxicity is dependent on the shoot density in meadows. At a certain load, $\mathrm{NH}_{x}$ concentrations in the canopy will most likely be significantly lower in high shoot density meadows compared to beds with low shoot densities, because concentrations will be actively lowered through the direct uptake of $\mathrm{NH}_{x}$ by the leaves (Iizumi and Hattori 1982; Thursby and Harlin 1982). Thus, it can be expected that a certain load may cause severe toxicity in a low density bed whereas the effect will be much less severe or even absent in a high density seagrass bed.

In this study, we investigated the interactive effects of $\mathrm{NH}_{x}, \mathrm{pH}$, and shoot density in the water layer on the physiology and survival of the seagrass Zostera marina (commonly called eelgrass). We conducted two laboratory experiments. First, we tested the eelgrass long-term tolerance for $\mathrm{NH}_{x}$ at natural sea water $\mathrm{pH}$. Secondly, we conducted an experiment to test the interactive effects of $\mathrm{NH}_{x}, \mathrm{pH}$, and shoot density on the short-term survival of eelgrass. Finally, we discuss the relevance of our results with regard to (eelgrass) physiology and ecology.

\section{Materials and methods}

After collection in the field, plants were stored at $10^{\circ} \mathrm{C}$ for transport to the laboratory in Nijmegen (Netherlands). Shoots (aboveground parts attached to at least $4 \mathrm{~cm}$ of rhizome) were acclimatized for 2 weeks in 100-1 glass containers $(1: \mathrm{w}: \mathrm{h}=80: 30: 45 \mathrm{~cm})$ that were placed in a climate controlled room at $20^{\circ} \mathrm{C}$. The culture medium used for acclimatization and the experiments was prepared from deionized water and Tropic Marin ${ }^{\odot}$ synthetic sea salt. We used a salinity equal to the level measured in the field. We set light intensity at $180 \mu \mathrm{mol} \mathrm{m}{ }^{-2} \mathrm{~s}^{-1}$ with a day:night cycle of $16: 8 \mathrm{~h}$. This is comparable to average light levels in the field during the growing season around depths of 2 $3 \mathrm{~m}$ (assuming a light attenuation coefficient of $0.5 \mathrm{~m}^{-1}$ ) (e.g., van der Heide et al. 2007), which is in the normal depth ranges of eelgrass (e.g., Nielsen et al. 2002a).

At the start of both experiments, we carefully selected healthy apical shoots, based on shoot length, number of leaves, and the percentage mortality (black coloration) of the leaves. Only shoots with four or five leaves and a mortality of less than 5\% in the three youngest leaves were used in the experiments. The plants were allowed to acclimatize for two additional days, after placement in the experimental units.

Long-term experiment

The goal of this experiment was to simulate the response of eelgrass to $\mathrm{NH}_{x}$ exposure in 'open ocean' conditions. Plants were obtained at the end of August from the Atlantic Ocean near the shores of Brest (France). Based on the literature, we expected the plants to show a strong response to $\mathrm{NH}_{x}$ exposure due to the low ambient nitrogen concentrations $( \pm 11 \mu \mathrm{M}$ total $\mathrm{N})$ and a relatively high salinity in this area ( \pm 33 PSU) (van Katwijk et al. 1999). The experiment was carried out in a 5-week period in 16 glass containers $(1: w: h=20: 20: 58 \mathrm{~cm})$ placed in a $20^{\circ} \mathrm{C}$ water bath. Each unit contained 201 of medium and $8 \mathrm{~cm}$ of sandy sediment from the sampling site. Two shoots were placed in each container (total shoot biomass $0.68 \pm 0.04 \mathrm{~g} \mathrm{DW}$ ). The culture medium in the containers was continuously replenished from stock containers at a renewal rate of twice a week, using Masterflex peristaltic pumps. We used four different treatments, resulting in four replicas per treatment. $\mathrm{NH}_{x}$ concentrations in the stock solutions were 20,60, 100, 
and $150 \mu \mathrm{mol} \mathrm{l}^{-1}$ by addition of $\mathrm{NH}_{4} \mathrm{Cl}$. We added $1 \mu \mathrm{mol} \mathrm{l}^{-1}$ cyanoguanidine to the stock solutions to prevent nitrification of ammonium (Smolders et al. 1996). The $\mathrm{pH}$ level was carefully kept between 8.0 and 8.2 by aerating the units with $\mathrm{CO}_{2}$ enriched air (5 ppt $\mathrm{CO}_{2}$ ), using mass flow controllers. The total dissolved inorganic carbon concentration (DIC) in the water was $2.2 \pm 0.02 \mathrm{mM}$, a close approximation of the DIC level of the sampling site $(2.3 \mathrm{mM})$. Water samples for analysis of $\mathrm{NH}_{x}$ and nitrate were taken on a weekly basis. Leaf growth, leaf number, and shoot biomass were determined before and after the experiment.

\section{Short-term experiment}

Alongside the 5-week experiment, we performed a 5-day experiment with eelgrass from the Atlantic Ocean (near Brest, see previous heading), focusing on the acute combined effects of $\mathrm{pH}$ and $\mathrm{NH}_{x}$ (setup, $\mathrm{pH}, \mathrm{NH}_{x}$ levels, and analyses were performed as described below). In this trial, we found severe necrosis in eelgrass leaves due to $\mathrm{NH}_{x}$ addition at pH 9.1 but not at $\mathrm{pH} 8.1$ (see Fig. S1 in Supplementary material). However, these results pose virtually no ecological relevance as raised $\mathrm{pH}$ levels almost only occur in sheltered eutrophicated estuaries with a much lower salinity due to nutrient-rich freshwater influence. Therefore, we repeated this experiment at a lower salinity, using plants collected from the Baltic Sea near Kiel (Germany) at the end of August 2006. We expected this population to respond somewhat more conservatively to $\mathrm{NH}_{x}$ exposure compared to the Brest population, as nitrogen loads in the Baltic Sea are higher $( \pm 27 \mu \mathrm{M}$ ambient total $N)$ and salinity is much lower ( $\pm 16 \mathrm{PSU})$ compared to the waters around Brest (van Katwijk et al. 1999). The experiment was conducted in round glass columns containing 41 of medium $(\varnothing: \mathrm{h}=11: 45 \mathrm{~cm})$ placed in a water bath at $20^{\circ} \mathrm{C}$. We used four $\mathrm{NH}_{x}$ concentrations $\left(0,50,100\right.$, and $250 \mu \mathrm{mol} \mathrm{l}^{-1}$ added as $\mathrm{NH}_{4} \mathrm{Cl}$ ) at two $\mathrm{pH}$ levels (8.1 and 9.1). Additional to the initial setup of the short-term trial, we used two shoot densities at the highest $\mathrm{pH}$ to investigate a possible density dependent effect: 1 or 10 shoots per container, corresponding to 88 and 884 shoots $\mathrm{m}^{-2}$ (total shoot biomass $0.44 \pm 0.12$ and $4.25 \pm 0.28 \mathrm{~g} \mathrm{DW}$, respectively). At pH 8, experiments were performed using low shoot densities only, as a much lower toxicity was expected. In total, we used 48 glass columns, resulting in four replicas per treatment. Because of the short experimental period, plants could be maintained without sediment (e.g., Thursby and Harlin 1982; Rubio et al. 2007). This prevented $\mathrm{NH}_{x}$ loss due to nitrification or adsorption to sediment particles. Shoots were positioned in the columns by attaching stainless steel nuts to the rhizomes. As $\mathrm{NH}_{x}$ affinity is much higher for leaves than for roots (Iizumi and Hattori 1982; Thursby and Harlin 1982) and because uptake via roots and rhizomes is strongly limited in eelgrass when aboveground tissues are exposed to $\mathrm{NH}_{x}$ (Thursby and Harlin 1982), we assumed that $\mathrm{NH}_{x}$ assimilation through the remaining belowground tissue was negligible in our experiment. During the experiment, the culture medium was replenished each day at the start of the light period. The $\mathrm{pH}$ was checked regularly during the day and kept between 8.0 and 8.2 or 9.0 and 9.2 , by adding $\mathrm{HCl}$ or $\mathrm{NaOH}$. DIC of the 16 PSU water was $1.85 \pm 0.03 \mathrm{mM}$, comparable to the values measured at the sampling site $(1.88 \mathrm{mM})$. Water samples for analysis of $\mathrm{NH}_{x}$ were taken daily just before replenishment.

\section{Analysis of leaf tissue fitness}

After each experiment, we examined the fitness of the leaves by scanning the three youngest leaves of each shoot at $600 \mathrm{dpi}$, resulting in a resolution of over half a million pixels per leaf. We subsequently analyzed the scans using Adobe Photoshop. First, we eliminated background noise in the picture using the "threshold" function. The image was then converted into a 64-color index picture (redgreen-blue scheme). Next, we used the "color range" function to distinguish between dead and living leaf tissues. The amount of green coloration per pixel was used to determine whether leaf tissue was either dead or alive. Based on tests with fit and dead leaves from the field, we found that pixels with a green value of over $70( \pm 2$; on a scale of $0-255$ ) should be considered alive while lower values could be regarded as dead tissue. Based on this procedure, dead, living, and background areas in the picture were then colored in the three primary screen colors (red, green and blue). Finally, we calculated the percentage of living and dead tissues from the histogram values of the image.

\section{Chemical analyses}

Water samples taken during both experiments were analyzed for $\mathrm{NH}_{x}$ and nitrate (Tomassen et al. 2003). $\mathrm{NH}_{x}$ concentrations were determined spectrophotometrically using hypochlorite. Nitrate was measured spectrophotometrically with sulphanilamide after reduction of nitrate to nitrite in a cadmium column.

Free amino acids in the leaves of the shoots were extracted from healthy looking tissues, according to Van Dijk and Roelofs (1988). After extraction, amino acid concentrations were measured after pre-column derivatisation with 9-fluorenylmethyl-chloroformate (FMOC-Cl), using high pressure liquid chromatography (HPLC) (Tomassen et al. 2003). C:N ratios and total $\mathrm{N}$ concentrations were determined in freeze-dried leaf tissues by an CNS analyzer (type NA1500; Carlo Erba Instruments, Milan, Italy). 
Fig. 1 Effects of four $\mathrm{NH}_{x}$ input concentrations on eelgrass (Zostera marina) leaf tissues (mean $\pm \mathrm{SE}$ ) in the long-term experiment: a total nitrogen $(\mathrm{N})$ content, b C:N ratio, $\mathbf{c}$ free amino acid $\mathrm{N}$ relative to total $\mathrm{N}$ content, and $\mathbf{d}$ glutamine $\mathrm{N}$ relative to the total free amino acid $\mathrm{N}$ content
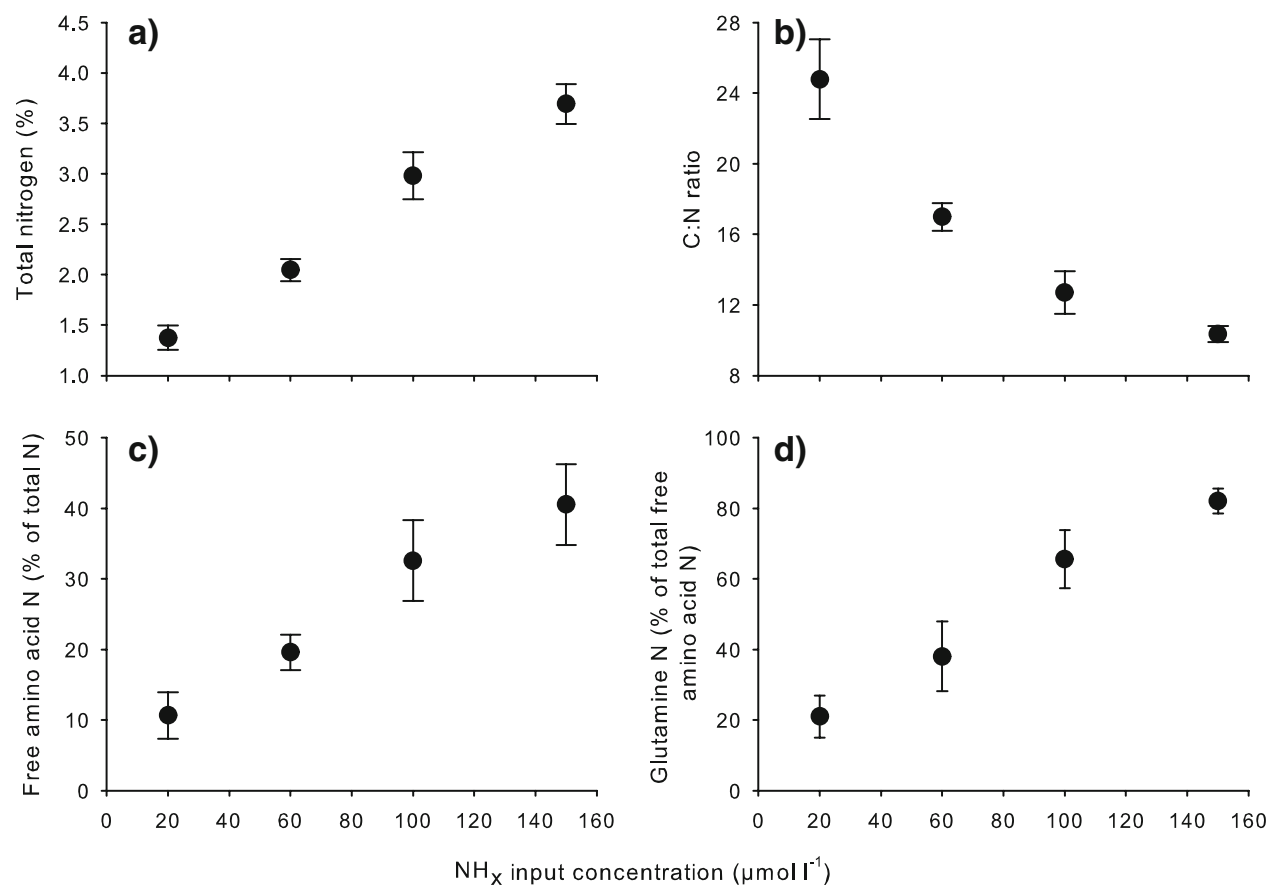

\section{Statistical analyses}

For all relevant variables, the effects of $\mathrm{NH}_{x}$ in the longterm experiment and $\mathrm{NH}_{x}, \mathrm{pH}$, density and their interactions in the short-term experiment were tested by analyses of variance (ANOVA) and multifactor ANOVA, respectively. Prior to the analyses, outliers were omitted based on Dixons' $Q$ test (Dean and Dixon 1951) and data were tested for normality. For multiple comparisons of normally distributed means (post hoc tests), we used independent samples $t$ tests. In the long-term experiment, we compared the effect of $\mathrm{NH}_{x}$ between treatments (6 tests). For the short-term experiment, we evaluated the effect of $\mathrm{NH}_{x}$ in all $\mathrm{pH}$ and density treatments (18 tests), compared group means of both $\mathrm{pH}$ levels at low density (4 tests) and tested the effect of density in the $\mathrm{pH}$ nine treatments (4 tests). Thus, 26 hypotheses were tested in total. Type I error in the testing procedures was controlled using the false discovery rate method $\left(P^{*}=0.05\right)$ (Benjamini and Hochberg 1995; Verhoeven et al. 2005).

\section{Results}

\section{Long-term experiment}

Data were normally distributed and no outliers were detected. Within 1 week, $\mathrm{NH}_{x}$ concentrations in the different treatments stabilized at $1,12,38$, and $75( \pm 2) \mu \mathrm{mol} 1^{-1}$. Nitrate levels were negligible in all treatments during the entire experimental period. After 5 weeks, we found no significant change in biomass, leaf growth, or in number of leaves. Moreover, shoots in all treatments looked healthy and leaf survival showed no trend at all, being over $90 \%$ in all treatments. In contrast, ANOVA revealed significant differences for internal nitrogen concentrations $(F=34.9$, $P<0.001)$ and $\mathrm{C}: \mathrm{N}$ ratios $(F=21.9, P<0.001)$ in the leaf tissues. Post hoc test showed that, apart from the two highest loads, all treatments differed significantly from each other for both variables. The total nitrogen content in the leaves ranged from 1.4 to $3.7 \%$ from the lowest to the highest treatments, respectively (Fig. 1a). Average $\mathrm{C}: \mathrm{N}$ ratios varied from 25 in the lowest to 10 in the highest treatments (Fig. 1b).

The amount of nitrogen that was stored as free amino acids in the tissues varied substantially with the applied $\mathrm{NH}_{x}$ load. Concentrations of free amino acid $\mathrm{N}$ increased significantly from $113 \mu \mathrm{mol} \mathrm{N} / \mathrm{g} \mathrm{DW}$ in the lowest $\mathrm{NH}_{x}$ treatment to $1,093 \mu \mathrm{mol} / \mathrm{g} \mathrm{DW}$ in the highest treatment (ANOVA, $F=10.3, P=0.001$ ). The percentage of total tissue nitrogen stored as free amino acids varied from 11 in the lowest to $41 \%$ in the highest treatment (ANOVA, $F=8.6, P=0.003$; Fig. 1c). Excess nitrogen in the shoots was primarily stored as glutamine. The percentage of glutamine in the total free amino acid concentration changed from $21 \%$ in the lowest to $82 \%$ in the highest $\mathrm{NH}_{x}$ treatment (ANOVA, $F=13.9, P<0.001$; Fig. 1d). Post hoc tests revealed significant differences between the lowest and the two highest loads for all three variables. Additionally, the $60 \mu \mathrm{mol}^{-1} \mathrm{NH}_{x}$ treatment also differed significantly with the highest load for these variables. 
Table 1 Results of the multi-factor ANOVAs on all relevant variables in the short-term experiment

\begin{tabular}{|c|c|c|c|c|c|}
\hline & $\mathrm{NH}_{x}$ treat. & $\mathrm{pH}$ & Density & $\mathrm{NH}_{x}$ treat. $\times \mathrm{pH}$ & $\mathrm{NH}_{x}$ treat. $\times$ density \\
\hline Leaf tissue survival (\%) & $29.1 * * *$ & $92.1 * * *$ & $82.9 * * *$ & $20.7 * * *$ & $13.6 * * *$ \\
\hline Total N (\%) & $92.8 * * *$ & $4.3 *$ & $6.6^{*}$ & $3.3 *$ & $2.9 \mathrm{~ns}$ \\
\hline $\mathrm{C}: \mathrm{N}$ ratio $(\mathrm{g}: \mathrm{g})$ & $64.8 * * *$ & $0.7 \mathrm{~ns}$ & $5.9 *$ & $0.4 \mathrm{~ns}$ & $2.2 \mathrm{~ns}$ \\
\hline Free amino acids $\mathrm{N}$ of tot. $\mathrm{N}(\%)$ & $313.8 * * *$ & $96.0 * * *$ & $7.9 * *$ & $46.1 * * *$ & $4.7 * *$ \\
\hline Total free amino acids $\mathrm{N}\left(\mu \mathrm{mol} 1^{-1}\right)$ & $339.6 * * *$ & $112.0 * * *$ & $7.8 * *$ & $79.2 * * *$ & $5.8 * *$ \\
\hline Glutamine $\mathrm{N}$ of tot. amino acids $\mathrm{N}(\%)$ & $339.8 * * *$ & $2.1 \mathrm{~ns}$ & $49.9 * * *$ & $1.8 \mathrm{~ns}$ & $18.0 * * *$ \\
\hline $\mathrm{NH}_{x}$ conc. after $24 \mathrm{~h}\left(\mu \mathrm{mol} 1^{-1}\right)$ & $3514.4 * * *$ & $11.0 * *$ & $887.6 * * *$ & $0.622 \mathrm{~ns}$ & $212.5 * * *$ \\
\hline
\end{tabular}

All data were normally distributed, except for total nitrogen. This variable obtained normality after inverse transformation $F$ values and significance levels are shown for all main effects and their interactions

$* 0.01 \leq P \leq 0.05 ; * * 0.001 \leq P<0.01 ; * * * P<0.001$

\section{Short-term experiment}

Analysis showed that all data were normally distributed and that 2 outliers should be excluded. Survival was significantly affected by $\mathrm{NH}_{x}, \mathrm{pH}$, density, and their interactions (ANOVA, Table 1). Leaf tissue survival ranged from $94 \%$ in the controls to $57 \%$ in the $250 \mu \mathrm{mol} 1^{-1}$, pH 9 treatment. Necrosis in the leaf tissues was expressed as a typical brown-black discoloration (Fig. 2). Within the $\mathrm{pH} 8$ treatment, there was no significant effect of any of the $\mathrm{NH}_{x}$ loads on leaf tissue survival. At $\mathrm{pH} 9, \mathrm{NH}_{x}$ significantly affected survival in both density treatments, but the intensity of the effects was clearly different. In the high density columns, only the highest $\mathrm{NH}_{x}$ treatment deviated significantly from the control treatment, whereas in the low density columns both the 50 and $250 \mu \mathrm{mol} \mathrm{l}^{-1} \mathrm{NH}_{x}$ treatments differed significantly from the control (and from each other) (Fig. 3a). The effects of $\mathrm{pH}$ and density were significant in the 50 and $250 \mu \mathrm{mol} 1^{-1} \mathrm{NH}_{x}$ treatments.

Total nitrogen content ranged from $1.5 \%$ in the control treatments to $2.6 \%$ in the $250 \mu \mathrm{mol} \mathrm{l}^{-1}, \mathrm{pH} 8$ treatment (Fig. 3b). The effect of the $\mathrm{NH}_{x}$ treatments was highly significant (Table 1). Multiple comparison tests on the $\mathrm{NH}_{x}$ treatments were significant in 13 out 16 cases. The effect of $\mathrm{pH}$ was only significant in the $250 \mu \mathrm{mol}^{-1}$ treatment, whereas density was significant in the $100 \mu \mathrm{mol}^{-1}$ treatment. The $\mathrm{C}: \mathrm{N}$ ratio showed a trend that was inversely correlated with the total $\mathrm{N}$ content (Fig. 3c). The average ratio ranged from 27 in the control treatments to 15 in the $250 \mu \mathrm{mol}^{-1}, \mathrm{pH} 8$ treatment.

The percentage of nitrogen that was stored in free amino acids increased significantly with increased $\mathrm{NH}_{x}$ loads (significant in 14 out of 16 tests). Contents ranged from $3 \%$ in the controls to a maximum of $39 \%$ in the $250 \mu \mathrm{mol} \mathrm{l}^{-1}, \mathrm{pH}$ 8 treatment (Fig. 3d), equaling 36 and $702 \mu \mathrm{mol}$ free amino acid N/g DW, respectively. The effect of $\mathrm{pH}$ was significant in the 50 and $250 \mu \mathrm{mol}^{-1}$ treatments, whereas density showed significant effects in the 50 and $100 \mu \mathrm{mol} \mathrm{l}^{-1}$

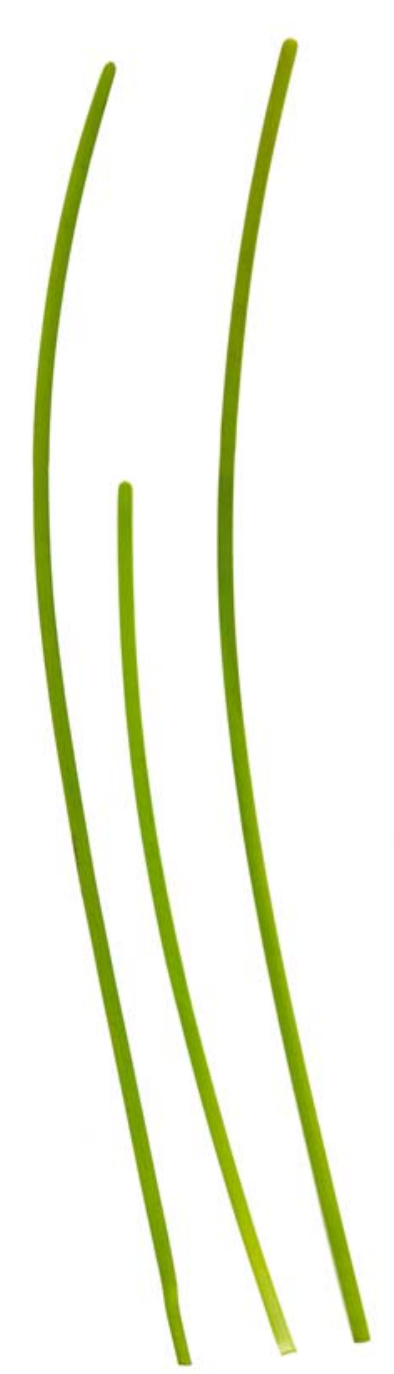

a) $0 \mu \mathrm{M}, \mathrm{pH} 8$, low density

b) $250 \mu \mathrm{M}, \mathrm{pH} 9$, low density

Fig. 2 Eelgrass leaves from a $0 \mu \mathrm{mol} 1^{-1}$ and b $250 \mu \mathrm{mol} 1^{-1} \mathrm{NH}_{x}$ input concentration treatments at low density $\mathrm{pH} 9$ at the end of the short-term experiment. The brown-black discoloration in $\mathbf{b}$ typifies leaf necrosis 
Fig. 3 Effects of the applied $\mathrm{NH}_{x}$ input concentrations (mean $\pm \mathrm{SE}$ ) in the short-term experiment: a leaf tissue survival, $\mathbf{b}$ total nitrogen $(\mathrm{N})$ content, $\mathbf{c} \mathrm{C}: \mathrm{N}$ ratio, $\mathbf{d}$ free amino acid $\mathrm{N}$ relative to total $\mathrm{N}$ content, e glutamine $\mathrm{N}$ relative to total free amino acid $\mathrm{N}$ content and $\mathbf{f}$ $\mathrm{NH}_{x}$ concentration after $24 \mathrm{~h}$
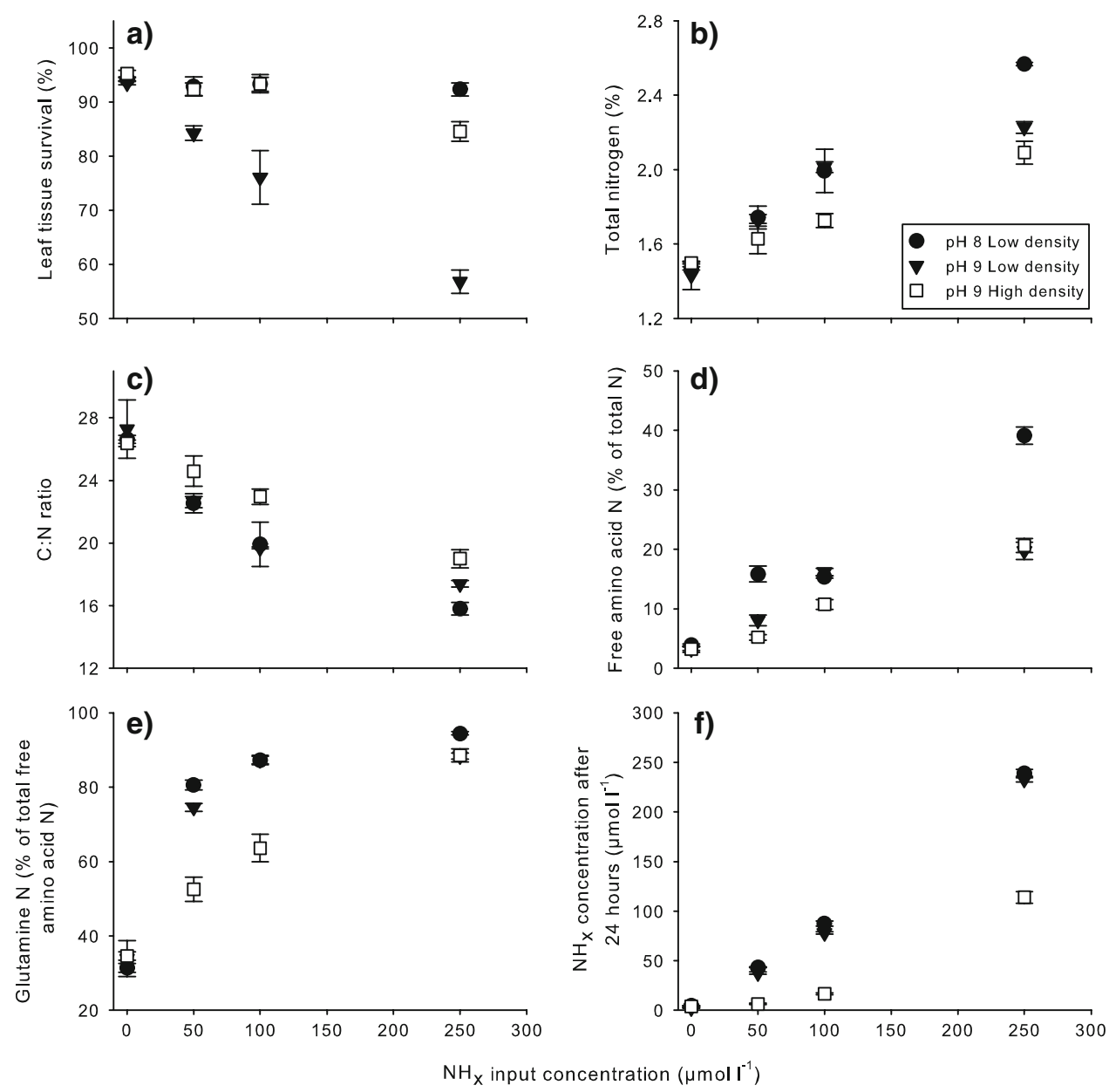

treatments. As in the long-term experiment, excess nitrogen was primarily stored as glutamine. The percentage of glutamine $\mathrm{N}$ in the total free amino acid $\mathrm{N}$ concentration varied from $33 \%$ in the $0 \mu \mathrm{mol} 1^{-1}$ treatments to $94 \%$ in the $250 \mu \mathrm{mol} \mathrm{l}^{-1}$, pH 8 treatment (Fig. 3e).

The $\mathrm{NH}_{x}$ concentration after $24 \mathrm{~h}$ was reduced to values around 6 and $17 \mu \mathrm{mol} 1^{-1}$ in the high density 50 and $100 \mu \mathrm{mol} 1^{-1}$ treatment, respectively. In the $250 \mu \mathrm{mol} 1^{-1}$ treatments, $\mathrm{NH}_{x}$ concentrations were still well above $100 \mu \mathrm{mol}^{-1}$ (Fig. 3f). The reduction of $\mathrm{NH}_{x}$ in the low density treatments was much smaller. The average total uptake ranged from around $10 \mu \mathrm{moll}^{-1} \mathrm{day}^{-1}$ in the $50 \mu \mathrm{mol} \mathrm{l}^{-1}$ treatments to $14 \mu \mathrm{mol} \mathrm{l}^{-1}$ day $^{-1}$ in the $250 \mu \mathrm{mol} \mathrm{l}^{-1}$ treatments. $\mathrm{NH}_{x}$ concentrations in the low density $\mathrm{pH} 9$ treatments were slightly but significantly lower compared to their counterparts in the $\mathrm{pH} 8$ treatments.

\section{Discussion}

Stress caused by reduced nitrogen in the water layer in seagrasses and other macrophytes has been frequently observed (e.g., Agami et al. 1976; Smolders et al. 1996; van Katwijk et al. 1997; Bird et al. 1998; Körner et al. 2001; Brun et al. 2002; Cao et al. 2004; Cao et al. 2007; Nimptsch and Pflugmacher 2007). However, the nature of the reported symptoms differ widely. Typical responses are free amino acid accumulation, oxidative stress, inhibited growth, and structural tissue damage. Results from our experiments suggest that differences in response may at least in part be explained by differences in $\mathrm{pH}$ of the medium. $\mathrm{NH}_{x}$ toxicity is the sum of the effects caused by $\mathrm{NH}_{4}{ }^{+}$and (gaseous) $\mathrm{NH}_{3}$ (Nimptsch and Pflugmacher 2007), and the balance between $\mathrm{NH}_{3}$ and $\mathrm{NH}_{4}{ }^{+}$levels in the $\mathrm{NH}_{x}$ concentration in turn depends on $\mathrm{pH}$ (Johansson and Wedborg 1980).

In our first, long-term experiment, conducted at a normal $\mathrm{pH}$ level ( $\mathrm{pH} 8.1$ ), structural tissue damage did not appear. However, internal nitrogen concentrations increased linearly with increasing $\mathrm{NH}_{x}$ loads and were much higher than commonly reported for eelgrass. In the $150 \mu \mathrm{M}$ treatment, total $\mathrm{N}$ concentrations in the eelgrass leaf tissues were higher than maximum values and nearly 1.5 times higher than average values reported from the field (Duarte 1990). Moreover, free amino acid N concentrations were also much higher than the highest value 
reported in literature (Touchette and Burkholder 2002) and consisted mainly of glutamine (around $88 \%$ ). These results indicate that, like many plants susceptible to $\mathrm{NH}_{4}{ }^{+}$toxicity, eelgrass shoots may not be able to exclude $\mathrm{NH}_{4}{ }^{+}$when exposed to high $\mathrm{NH}_{4}{ }^{+}$levels (Britto et al. 2001; Kronzucker et al. 2001). To prevent accumulation, $\mathrm{NH}_{x}$ then needs to be assimilated by the plant. Glutamine is often the main compound formed in this process, because it is the first amino acid formed in the $\mathrm{NH}_{x}$-assimilation cycle of plants (Märschner 1995).

In our second, short-term experiment, leaf survival in the low density treatments was strongly affected by the applied $\mathrm{NH}_{x}$ load at $\mathrm{pH} 9$, whereas no effects were visible at $\mathrm{pH}$ 8. At first sight, these results may suggest that the observed necrosis should be attributed to increased diffusion of $\mathrm{NH}_{3}$ into the tissues. After all, the concentration of this species is much higher at $\mathrm{pH} 9(28.5 \%$ of $\mathrm{NH}_{x}$ ) than at $\mathrm{pH} 8\left(3.8 \%\right.$ of $\left.\mathrm{NH}_{x}\right)$ (Johansson and Wedborg 1980). However, this explanation alone does not seem satisfactory, as both the long-term experiment and the $\mathrm{pH} 8$ treatments of the short-term experiment demonstrated that nitrogen also accumulated strongly at $\mathrm{pH}$ 8 in eelgrass at the applied $\mathrm{NH}_{x}$ concentrations. It seems likely that disruption of the carbon assimilation (through photosynthesis) rendered the plants susceptible to enhanced external $\mathrm{NH}_{x}$ concentrations at $\mathrm{pH} \mathrm{9}$, as the carbon consuming $\mathrm{NH}_{x}$ assimilation becomes impaired when carbon availability is limited (Märschner 1995). Even though eelgrass is able to utilize bicarbonate $\left(\mathrm{HCO}_{3}{ }^{-}\right)$next to carbon dioxide $\left(\mathrm{CO}_{2}\right)$ for carbon assimilation, carbon may become limited at $\mathrm{pH} 9$ when the total dissolved inorganic carbon (DIC) concentration is at a natural sea water level $( \pm 2.2 \mathrm{mM})$ (Sand-Jensen and Gordon 1984). This is because with rising $\mathrm{pH}, \mathrm{CO}_{2}$ and $\mathrm{HCO}_{3}{ }^{-}$levels drop in favor of $\mathrm{CO}_{3}{ }^{2-}$, a carbon species which cannot be assimilated. Next, high intracellular $\mathrm{NH}_{x}$ concentrations may cause uncoupling of photophosphorylation by $\mathrm{NH}_{3}$ in the chloroplasts, further decreasing photosynthesis and related carbon uptake (e.g., Pearson and Stewart 1993; Märschner 1995). This hypothesis is supported by the analyses of the tissue nitrogen compounds in the short-term experiment. Free amino acid and total $\mathrm{N}$ concentrations were lower instead of higher in the $\mathrm{pH} 9$ treatments, suggesting that, despite a possible increased intrusion of $\mathrm{NH}_{3}, \mathrm{NH}_{x}$ assimilation rates were lower at $\mathrm{pH} 9$.

Another important outcome of the short-term experiment is that a high density of eelgrass was able to buffer for $\mathrm{NH}_{x}$ toxicity up to a load of $100 \mu \mathrm{mol} 1^{-1} \mathrm{NH}_{x}$ per day, as necrosis only appeared in the highest $\mathrm{NH}_{x}$ treatment. Even though these high density treatments must also have experienced carbon limitation and impaired photosynthesis, survival of the plants was not affected in the three lower $\mathrm{NH}_{x}$ treatments. Additionally, total tissue nitrogen and free amino acid concentrations were significantly lower in the high density treatments compared to their low density counterparts. This indicates that the potential for $\mathrm{NH}_{x}$ toxicity was alleviated in the high density treatments through the joint uptake of $\mathrm{NH}_{x}$ by the shoots, thereby decreasing ambient $\mathrm{NH}_{x}$ concentrations below the threshold above which $\mathrm{NH}_{x}$ becomes toxic. This view is supported by the measured decrease of $\mathrm{NH}_{x}$ concentrations in the water column within $24 \mathrm{~h}$. The high density treatments were able to lower $\mathrm{NH}_{x}$ concentrations in the 50 and $100 \mu \mathrm{mol}^{-1}$ treatments to values well below $20 \mu \mathrm{mol}^{-1}$ within $24 \mathrm{~h}$.

The visual symptoms of $\mathrm{NH}_{x}$ toxicity that appeared in the $\mathrm{pH} 9$ treatments are much alike those reported by Van Katwijk et al. (1997). They also observed a typical brownblack discoloration of the eelgrass leaves within a period of 2 weeks. It is striking, however, that the experimental setup of Van Katwijk et al. was much more similar to the design of our long-term experiment. Both experiments were performed in the same laboratories, lasted 5 weeks, and were performed in glass containers with similar light conditions. Replenishment of the medium was continuous in both experiments, resulting in similar $\mathrm{NH}_{x}$ concentrations in the containers. However, in contrast to the results of Van Katwijk et al., we found no visual symptoms of $\mathrm{NH}_{x}$ toxicity in our long-term experiment. Moreover, the mean total tissue $\mathrm{N}$ concentration in our highest treatment was even higher than the highest reported value by Van Katwijk et al. In our opinion, these contradicting results can be best explained by differences in $\mathrm{pH}$. In our experiment, $\mathrm{pH}$ was carefully controlled. Van Katwijk et al. mention an average $\mathrm{pH}$ of 8.5 , which is already somewhat higher than in our experiment (8.0-8.2), but additionally $\mathrm{pH}$ was not controlled in their experiment. This lack of $\mathrm{pH}$ control most likely allowed for $\mathrm{pH}$ fluctuations during the day due to photosynthetic activity. It is therefore not inconceivable that the photosynthetic activity of eelgrass plants may have caused $\mathrm{pH}$ spikes of around $\mathrm{pH} 9$ or even higher near the end of each day, leading to carbon limitation and impaired photosynthesis.

\section{Ecological implications}

At normal pH levels (i.e., 'open ocean' conditions, $\mathrm{pH}$ 8.1) and sufficient light for photosynthesis and carbon fixation, acute toxic effects may at least temporarily be prevented by the assimilation of $\mathrm{NH}_{4}{ }^{+}$into free amino acid compounds (van Katwijk et al. 1997; Brun et al. 2002). However, the observed disproportional accumulation of glutamine can be considered an indication of physiological stress due to the elevated $\mathrm{NH}_{4}{ }^{+}$levels in the water layer (Näsholm et al. 1994; Huhn and Schulz 1996; Smolders et al. 2000). Such a chronic exposure to $\mathrm{NH}_{4}{ }^{+}$(i.e., several months or years) 
will most likely lead to the classically reported visual symptoms like chlorosis of leaves and the suppression of growth (Britto and Kronzucker 2002). Moreover, phenolic content in the leaves will decrease, due to a changed allocation of carbon skeletons, making the plant more susceptible to pathogens like the "wasting disease", which destroyed many eelgrass stands in the 1930s (Buchsbaum et al. 1990; van Katwijk et al. 1997; Vergeer and Develi 1997).

Although high $\mathrm{NH}_{x}$ levels in the water layer at $\mathrm{pH} 8$ most likely cause stress in eelgrass when exposed for longer periods of time, results from our experiments demonstrate that acute toxicity and sudden collapse through mass mortality will probably not occur as long as sufficient light is available. In contrast, elevated $\mathrm{NH}_{x}$ concentrations at enhanced $\mathrm{pH}$ levels (i.e., $\mathrm{pH}$ 9) can cause severe mortality in eelgrass within days. Thus, mass mortality through $\mathrm{NH}_{x}$ toxicity can be of significant importance in for instance sheltered eutrophicated estuaries, where phytoplankton, macroalgae, and eelgrass itself can cause high $\mathrm{pH}$ levels as well as $\mathrm{NH}_{x}$ spikes near the end of the growing season. Additionally, the mechanism may also be important at a normal $\mathrm{pH}$ during phytoplankton blooms or along eelgrass depth limits as light availability is poor in those cases.

Interestingly, our results show that the severity of the toxic effect is most likely strongly dependent upon the shoot density of an eelgrass bed. Especially in sheltered stagnant estuaries where mixing between the eelgrass canopy and its surroundings is poor, this could lead to a positive feedback: once there is a high density of eelgrass, its susceptibility to $\mathrm{NH}_{x}$ toxicity becomes lower. If such positive feedback is strong enough, it can lead to alternative stable states in seagrasses (Scheffer et al. 2001; van der Heide et al. 2007). However, in our case, the feedback mechanism may be more complex: a high eelgrass density can also imply a higher photosynthetic activity and thus a higher $\mathrm{pH}$, which in turn may lead to a higher toxicity. Therefore, the outcome in a particular field situation will strongly depend on the $\mathrm{NH}_{x}$ loads, the photosynthetic activity, and the exchange rates between the seagrass meadow and the surrounding water layer (van Nes and Scheffer 2005). The occurrence of alternative stable states may at least in part explain the worldwide observed seemingly high resilience to change, sudden ecosystem collapses, and mass mortalities in seagrasses (van der Heide et al. 2007).

Acknowledgments We wish to thank two anonymous referees for their valuable comments on earlier versions of the manuscript. We are also grateful to Mr. W. van der Heide, Mr. M. G. Versteeg, Mrs. D. C. R. Hermus, Mr. G. M. Bögeman, Mr. M. van der Gaag and Mr. J. Eygensteyn for their help with the experiments. Finally, we like to thank the Tropic Marin company for supplying us with their Tropic Marin Classic synthetic sea salt. This study is financially supported by the Netherlands Organization of Scientific Research/Earth and Life Sciences (NWO-ALW).
Open Access This article is distributed under the terms of the Creative Commons Attribution Noncommercial License which permits any noncommercial use, distribution, and reproduction in any medium, provided the original author(s) and source are credited.

\section{References}

Agami M, Litav M, Waisel Y (1976) The effects of various components of water pollution on the behaviour of some aquatic macrophytes of the coastal rivers of Israel. Aquat Bot 2:203-213

Azzoni R, Giordani C, Bartoli M, Welsh DT, Viaroli P (2001) Iron, sulphur and phosphorus cycling in the rhizosphere sediments of a eutrophic Ruppia cirrhosa meadow (Valle Smarlacca, Italy). J Sea Res 45:15-26

Benjamini Y, Hochberg Y (1995) Controlling the false discovery rate-a practical and powerful approach to multiple testing. J R Stat Soc Ser B-Methodol 57:289-300

Bird KT, Johnson JR, Jewett-Smith J (1998) In vitro culture of the seagrass Halophila decipiens. Aquat Bot 60:377-387

Britto DT, Kronzucker HJ (2002) $\mathrm{NH}_{4}^{+}$toxicity in higher plants: a critical review. J Plant Physiol 159:567-584

Britto DT, Siddiqi MY, Glass ADM, Kronzucker HJ (2001) Futile transmembrane $\mathrm{NH}_{4}{ }^{+}$cycling: a cellular hypothesis to explain ammonium toxicity in plants. Proc Natl Acad Sci USA 98:42554258

Brun FG, Hernandez I, Vergara JJ, Peralta G, Perez-Llorens JL (2002) Assessing the toxicity of ammonium pulses to the survival and growth of Zostera noltii. Mar Ecol Prog Ser 225:177-187

Buchsbaum RN, Short FT, Cheney DP (1990) Phenolic-nitrogen interactions in eelgrass, Zostera marina $\mathrm{L}$-possible implications for disease resistance. Aquat Bot 37:291-297

Burkholder JM, Mason KM, Glasgow JHB (1992) Water-column nitrate enrichment promotes decline of eelgrass Zostera marina: evidence from seasonal mesocosm experiments. Mar Ecol Prog Ser 81:163-178

Cao T, Ni LY, Xie P (2004) Acute biochemical responses of a submersed macrophyte, Potamogeton crispus L., to high ammonium in an aquarium experiment. J Freshw Ecol 19:279-284

Cao $\mathrm{T}$ et al (2007) The role of $\mathrm{NH}_{4}^{+}$toxicity in the decline of the submersed macrophyte Vallisneria natans in lakes of the Yangtze River basin, China. Mar Freshw Res 58:581-587

Carlson PR, Yarbro LA, Barber TR (1994) Relationship of sediment sulfide to mortality of Thalassia testudinum in Florida Bay. Bull Mar Sci 54:733-746

Choo KS, Snoeijs P, Pedersen M (2002) Uptake of inorganic carbon by Cladophora glomerata (Chlorophyta) from the Baltic Sea. J Phycol 38:493-502

Dean RB, Dixon WJ (1951) Simplified statistics for small numbers of observations. Anal Chem 23:636-638

Duarte CM (1990) Seagrass nutrient content. Mar Ecol Prog Ser 67:201-207

Duarte CM (2002) The future of seagrass meadows. Environ Conserv 29:192-206

Farnsworth-Lee LA, Baker LA (2000) Conceptual model of aquatic plant decay and ammonia toxicity for shallow lakes. J Environ Eng Asce 126:199-207

Feike M, Heerkloss R, Rieling T, Schubert H (2007) Studies on the zooplankton community of a shallow lagoon of the Southern Baltic Sea: long-term trends, seasonal changes, and relations with physical and chemical parameters. Hydrobiologia 577:95-106

Goodman JL, Moore KA, Dennison WC (1995) Photosynthetic responses of eelgrass (Zostera marina $\mathrm{L}$ ) to light and sediment sulfide in a shallow barrier-island lagoon. Aquat Bot 50:37-47 
Hauxwell J, Cebrian J, Furlong C, Valiela I (2001) Macroalgal canopies contribute to eelgrass (Zostera marina) decline in temperate estuarine ecosystems. Ecology 82:1007-1022

Huhn G, Schulz H (1996) Contents of free amino acids in Scots pine needles from field sites with different levels of nitrogen deposition. New Phytol 135:95-101

Iizumi H, Hattori A (1982) Growth and organic production of eelgrass (Zostera marina $\mathrm{L}$ ) in temperate waters of the Pacific coast of Japan. 3. The kinetics of nitrogen uptake. Aquat Bot 12:245-256

Jackson JBC et al (2001) Historical overfishing and the recent collapse of coastal ecosystems. Science 293:629-638

Johansson O, Wedborg M (1980) The ammonia-ammonium equilibrium in seawater at temperatures between 5 and 25 degrees $\mathrm{C}$. J Solut Chem 9:37-44

Kemp WM et al (2005) Eutrophication of Chesapeake Bay: historical trends and ecological interactions. Mar Ecol Prog Ser 303:1-29

Körner S, Das SK, Veenstra S, Vermaat JE (2001) The effect of pH variation at the ammonium/ammonia equilibrium in wastewater and its toxicity to Lemna gibba. Aquat Bot 71:71-78

Körner S, Vermaat JE, Veenstra S (2003) The capacity of duckweed to treat wastewater: ecological considerations for a sound design. J Environ Qual 32:1583-1590

Kronzucker HJ, Britto DT, Davenport RJ, Tester M (2001) Ammonium toxicity and the real cost of transport. Trends Plant Sci 6:335-337

Landers DH (1982) Effects of naturally senescing aquatic macrophytes on nutrient chemistry and chlorophyll- $a$ of surrounding waters. Limnol Oceanogr 27:428-439

Märschner H (1995) The mineral nutrition of higher plants. Academic Press, London

Näsholm H, Edfast AB, Ericsson A, Nordon LG (1994) Accumulation of amino acids in some boreal plants in response to increased nitrogen availability. New Phytol 126:137-143

Nielsen SL, Sand-Jensen K, Borum J, Geertz-Hansen O (2002a) Depth colonization of eelgrass (Zostera marina) and macroalgae as determined by water transparency in Danish coastal waters. Estuaries 25:1025-1032

Nielsen SL, Sand-Jensen K, Borum J, Geertz-Hansen O (2002b) Phytoplankton, nutrients, and transparency in Danish coastal waters. Estuaries 25:930-937

Nimptsch J, Pflugmacher S (2007) Ammonia triggers the promotion of oxidative stresss in the aquatic macrophyte Myriophyllum mattogrossense. Chemosphere 66:708-714

Orth RJ et al (2006) A global crisis for seagrass ecosystems. Bioscience 56:987-996

Pearson J, Stewart GR (1993) The deposition of atmospheric ammonia and its effects on plants. New Phytol 125:283-305

Pedersen O, Binzer T, Borum J (2004) Sulphide intrusion in eelgrass (Zostera marina L.). Plant Cell Environ 27:595-602

Perez M, Invers O, Ruiz JM, Frederiksen MS, Holmer M (2007) Physiological responses of the seagrass Posidonia oceanica to elevated organic matter content in sediments: an experimental assessment. J Exp Mar Biol Ecol 344:149-160
Rubio L, Linares-Rueda A, García-Sánchez MJ, Fernández JA (2007) Ammonium uptake kinetics in root and leaf cells of Zostera marina L. J Exp Mar Biol Ecol 352(2):271-279

Sand-Jensen K, Gordon DM (1984) Differential ability of marine and freshwater macrophytes to utilize $\mathrm{HCO}$ and $\mathrm{CO}_{2}$. Mar Biol 80:247-253

Scheffer M, Carpenter S, Foley JA, Folke C, Walker B (2001) Catastrophic shifts in ecosystems. Nature 413:591-596

Smolders AJP, Den Hartog C, Van Gestel CBL, Roelofs JGM (1996) The effects of ammonium on growth, accumulation of free amino acids and nutritional status of young phosphorus deficient Stratiotes aloides plants. Aquat Bot 53:85-96

Smolders AJP, van Riel MC, Roelofs JGM (2000) Accumulation of free amino acids as an early indication for physiological stress (nitrogen overload) due to elevated ammonium levels in vital Stratiotes aloides L. stands. Arch Hydrobiol 150:169-175

Thursby GB, Harlin MM (1982) Leaf-root interaction in the uptake of ammonia by Zostera marina. Mar Biol 72:109-112

Tomassen HBM, Smolders AJP, Lamers LPM, Roelofs JGM (2003) Stimulated growth of Betula pubescens and Molinia cearulea on ombrotrophic bogs: role of high levels of atmospheric nitrogen deposition. J Ecol 91:357-370

Touchette BW, Burkholder JM (2000) Review of nitrogen and phosphorus metabolism in seagrasses. J Exp Mar Biol Ecol 250:133167

Touchette BW, Burkholder JM (2002) Seasonal variations in carbon and nitrogen constituents in eelgrass (Zostera marina L.) as influenced by increased temperature and water-column nitrate. Bot Mar 45:23-34

van der Heide T, van Nes EH, Geerling GW, Smolders AJP, Bouma TJ, van Katwijk MM (2007) Positive feedbacks in seagrass ecosystems-implications for success in conservation and restoration. Ecosystems 10:1311-1322

van Dijk HFG, Roelofs JGM (1988) Effects of excessive ammonium deposition on the nutritional-status and condition of pine needles. Physiol Plant 73:494-501

van Katwijk MM, Vergeer LHT, Schmitz GHW, Roelofs JGM (1997) Ammonium toxicity in eelgrass Zostera marina. Mar Ecol Prog Ser 157:159-173

van Katwijk MM, Schmitz GHW, Gasseling AP, van Avesaath PH (1999) Effects of salinity and nutrient load and their interaction on Zostera marina. Mar Ecol Prog Ser 190:155-165

van Nes EH, Scheffer M (2005) Implications of spatial heterogeneity for catastrophic regime shifts in ecosystems. Ecology 86:17971807

Vergeer LHT, Develi A (1997) Phenolic acids in healthy and infected leaves of Zostera marina and their growth-limiting properties towards Labyrinthula zosterae. Aquat Bot 58:65-72

Verhoeven KJF, Simonsen KL, McIntyre LM (2005) Implementing false discovery rate control: increasing your power. Oikos 108:643-647 